\title{
ANALISIS YURIDIS TERHADAP LEGALITAS DOKUMEN ELEKTRONIK SEBAGAI ALAT BUKTI DALAM PENYELESAIAN SENGKETA
}

\author{
Aloina Sembiring Meliala \\ Fakultas Hukum Universitas Katolik Parahyangan \\ E-mail: aloisembiring@yahoo.com
}

\begin{abstract}
The development of information and communication technologies lead the world into a borderless relationship. One of the problems that occursis that; the electronic transaction for trading activity through the electronic system (electronic commerce). This transaction yields electronic documents as regulated in Act No. 11 year of 2008 article 1 paragraph 4 on Information and Electronic Transactions. The method used in this research is normative juridical approach with descriptive analytical. Electronic documents can be categorized as valid written evidence in the form of a deed under the hand, so it has the same legal force asthe document written on paper and can be used as evidence in the event of a dispute between the parties in terms of proving the existence of an agreement.
\end{abstract}

Keywords: electronic documents; legality; e-commerce.

\begin{abstract}
Abstrak
Perkembangan teknologi informasi dan komunikasi menyebabkan hubungan dunia menjadi tanpa batas (borderless). Salah satu permasalahan yang terjadi adalah adanya transaksi elektronik untuk kegiatan perdagangan melalui sistem elektronik (electronic commerce). Dengan adanya transaksi tersebut menghasilkan dokumen elektronik seperti yang diatur dalam Pasal 1 angka 4 Undang-Undang Nomor 11 Tahun 2008 Tentang Informasi dan Transaksi Elektronik. Metode penelitian yang digunakan dalam penelitian ini adalah pendekatan yuridis normatif dengan deskriptif analitis. Dokumen elektronik dapat dikategorikan sebagai alat bukti tertulis yang sah berupa akta di bawah tangan, sehingga memiliki kekuatan hukum yang sama dengan dokumen yang tertulis di atas kertas dan dapat dijadikan sebagai alat bukti apabila terjadi sengketa di antara para pihak dalam hal pembuktian adanya suatu perjanjian.
\end{abstract}

Kata Kunci: Dokumen Elektronik, Legalitas, E-commerce.

\section{A. PENDAHULUAN}

Kehidupan masyarakat dunia termasuk Indonesia semakin berkembang ke arah yang lebih modern. Perkembangan ini diiringi dengan adanya perkembangan bidang teknologi yang sangat pesat di berbagai negara, yang secara tidak langsung mempengaruhi aspek-aspek dalam kehidupan manusia. Salah satu perkembangan tersebut adalah perkembangan dalam bidang teknologi informasi dan komunikasi. Wujud dari 
perkembangan teknologi informasi dan komunikasi tersebut adalah berupa internet (interconection networking) yaitu suatu koneksi antar jaringan komputer. Penggunaan internet saat ini telah memasuki berbagai aktivitas manusia, baik dalam sektor politik, sosial, budaya, ekonomi dan bisnis.

Perkembangan internet menciptakan terbentuknya suatu dunia baru yang biasa disebut dengan dunia maya (cyber space), di mana setiap individu yang satu dengan yang lain dapat berhubungan tanpa batasan dan tidak perlu bertatap muka. Dengan adanya teknologi berupa internet merubah gaya hidup dan perilaku masyarakat dunia yang biasanya informasi dan komunikasi dilakukan dengan menggunakan kertas (paper), berubah menjadi elektronik (paperless).

Dalam dunia maya, masyarakat melakukan berbagai kegiatan di berbagai bidang, termasuk transaksi-transaksi yang membawa konsekuensi tertentu di bidang hukum. Transaksi tersebut adalah kegiatan yang menimbulkan hak dan kewajiban bagi para pihak yang terlibat dalam kegiatan tersebut sesuai dengan aturan-aturan hukum yang berlaku. Kegiatan dalam bidang hukum di dunia maya mencakup segala bidang hukum, seperti, perdata, pidana, bisnis, dll.

Dalam dunia maya, banyak terjadi transaksi dalam bidang hukum bisnis. Salah satu kegiatan yang sering dilakukan adalah kegiatan perdagangan. Dengan latar belakang tersebut, lahirlah suatu proses transaksi perdagangan yang dilakukan dalam dunia maya yaitu, transaksi perdagangan elektronik atau electronic commerce transaction yang biasa disebut dengan e-commerce. Menurut Mariam Darus Badrulzaman istilah lain yang dipakai untuk e-commerce di antaranya kontrak dagang elektronik, kontrak siber, transaksi dagang elektronik, dan kontrak web. ${ }^{1}$

Electronic Commerce transaction adalah transaksi dagang antara penjual dan pembeli untuk menyediakan barang, jasa, atau mengambil alih hak melalui media elektronik dimana para pihak tidak hadir secara fisik dan menggunakan jaringan umum dengan sistem terbuka yaitu internet. Berbeda dengan transaksi perdagangan biasa, transaksi $e$-commerce memiliki beberapa karakteristik yang sangat khusus, yaitu: ${ }^{2}$

1. Transaksi tanpa batas

Sebelum era internet, batas-batas geografi menjadi penghalang suatu perusahaan atau individu yang ingin go-international. Sehingga, hanya perusahaan atau individu dengan modal besar yang dapat memasarkan produknya ke luar negeri. Dewasa ini dengan internet pengusaha kecil dan menengah dapat memasarkan produknya secara internasional cukup dengan membuat situs web atau dengan memasang iklan di situs-situs internet tanpa batas waktu (24 jam),

1 Mariam Darus Badrulzaman, Mendambakan Kelahiran Hukum Saiber (cyber law) di Indonesia, Pidato diucapkan pada upacara memasuki masa Purna Bhakti sebagai Guru Besar Tetap Fakultas Hukum USU, Medan, Selasa 13 November 2001, bertempat di Hotel Danau Toba, Medan , hlm. 1.

2 Kisma Kartika, https://kismayuniputrikartika.wordpress.com/2013/03/22/karakteristik-e-commerce/ diunduh tanggal 1 September 2015. 
dan tentu saja pelanggan dari seluruh dunia dapat mengakses situs tersebut dan melakukan transaksi secara online.

2. Transaksi anonim

Para penjual dan pembeli dalam transaksi melalui internet tidak harus bertemu muka satu sama lainnya. Penjual tidak memerlukan nama dari pembeli sepanjang mengenai pembayarannya telah diotorisasi oleh penyedia sistem pembayaran yang ditentukan, yang biasanya dengan kartu kredit.

3. Produk digital dan non digital

Produk-produk digital seperti software komputer, musik dan produk lain yang bersifat digital dapat dipasarkan melalui internet dengan cara mendownload secara elektronik. Dalam perkembangannya objek yang ditawarkan melalui internet juga meliputi barang-barang kebutuhan hidup lainnya.

4. Produk barang tak berwujud Banyak perusahaan yang bergerak di bidang e-commerce dengan menawarkan barang tak berwujud separti data, software dan ide-ide yang dijual melalui internet.

Transaksi yang terjadi antara permintaan (demand) dan penawaran (supply) dapat dengan mudah dilakukan walaupun yang bersangkutan berada dalam sisi geografis yang berbeda karena kemajuan dan perkembangan teknologi informasi, yang dalam hal ini adalah teknologi e-commerce. ${ }^{3}$

Salah satu bidang hukum yang terkait dengan adanya transaksi via e-commerce adalah bidang hukum kontrak. Hal ini dikarenakan kebanyakan dari kesepakatan dalam bisnis termasuk bisnis lewat e-commerce didasari atas suatu kontrak bisnis. ${ }^{4}$ Bidang-bidang dari hukum kontrak yang bersentuhan dengan bisnis e-commerce ini antara lain sebagai berikut: $^{5}$

1. Ada atau tidaknya penawaran (offer);

2. Ada atau tidaknya penerimaan (acceptance);

3. Ada atau tidaknya kata sepakat;

4. Jika ada kata sepakat, sejak kapan mulai ada;

5. Keharusan kontrak tertulis dan tanda tangan tertulis;

6. Masalah pembuktian perdata;

7. Bagaimana mengetahui para pihak dan kecakapan berbuat para pihak;

8. Perumusan kembali masalah wanprestasi;

9. Perumusan kembali masalah force majeure;

10. Ganti rugi yang bagaimana yang paling cocok untuk kontrak e-commerce;

11. Masalah kontrak berat sebelah dan kontrak baku.

Apabila suatu kontrak bisnis dilakukan melalui e-commerce, maka kontrak yang terjadi adalah berupa kontrak online atau elektronik. Kontrak elektronik adalah kontrak yang dirancang dibuat, ditetapkan,

3 R. Eko Indrajit, Manajemen Sistem Informasi dan Teknologi Informasi, PT. Elex Media Komputindo, Jakarta, 2001, hlm. 259.

4 Munir Fuady, Pengantar Hukum Bisnis Menata Bisnis Modern di Era Global, PT. Citra Aditya Bakti, Bandung, 2002, hlm. 409-410.

$5 \quad$ Ibid, hlm. 410. 
digandakan, dan disebarluaskan secara digital melalui situs di internet (website) secara sepihak oleh pembuat kontrak untuk ditutup secara digital pula oleh penutup kontrak. Di dalam kontrak elektronik terdapat ciri khas kontrak elektronik, yaitu: ${ }^{6}$

1. Kontrak elektronik dapat terjadi secara jarak jauh, bahkan melampaui batas-batas negara melalui internet;

2. Para pihak dalam kontrak elektronik pada umumnya tidak pernah bertatap muka (faceless nature), bahkan mungkin tidak pernah bertemu.

Berdasarkan Pasal 1313 KUH Perdata menjelaskan perjanjian adalah suatu perbuatan dengan mana satu orang atau lebih mengikatkan dirinya terhadap satu orang lain atau lebih. Dalam Pasal 1320 KUH Perdata, kontrak dianggap sah, apabila memenuhi syarat sebagai berikut:

\section{Sepakat (Toestemming)}

Kesesuaian, kecocokan, pertemuan kehendak dari yang mengadakan perjanjian atau pernyataan kehendak yang disetujui antara pihakpihak. Sebelum ada kesepakatan, para pihak-pihak mengadakan perundingan dahulu. Pihak yang satu memberitahukan kepada pihak lain mengenai objek perjanjian serta syarat-syaratnya, lalu pihak yang lain mengatakan pula kehendaknya, sehingga mencapai kesepakatan. ${ }^{7}$ Kesepakatan bersifat bebas, yaitu tidak ada paksaan atau tekanan dari pihak- pihak lain serta tidak ada penipuan dan kehilafan.

Unsur-unsur kesepakatan: ${ }^{8}$

a. Offerte (penawaran) adalah pernyataan pihak yang menawarkan.

b. Acceptasi (penerimaan) adalah pernyataan pihak yang menerima penawaran.

Kesepakatan termasuk hal yang penting untuk diketahui karena kepakatan merupakan awal terjadinya perjanjian. Untuk mengetahui kapan kesepakatan terjadi ada empat macam teori, yaitu: ${ }^{9}$

a. Teori Pernyataan.

Sepakat terjadi saat kehendak pihak yang menerima tawaran menyatakan bahwa ia menerima penawaran itu. Kelemahannya sangat teoritis karena dianggap terjadinya kesepakatan secara otomatis.

b. Teori Pengiriman.

Sepakat terjadi saat kehendak yang dinyatakan itu dikirim oleh pihak yang menerima tawaran.

c. Teori Pengetahuan.

Pihak yang menawarkan seharusnya sudah mengetahui bahwa tawarannya sudah diterima (walaupun penerimaan itu belum diterimanya dan tidak diketahui secara langsung).

d. Teori Penerimaan.

Kesepakatan terjadi pada saat pihak yang menawarkan

\footnotetext{
6 Johannes Gunawan, Reorientasi Hukum Kontrak di Indonesia, Jurnal Hukum Bisnis Volume 22 No. 6, Tahun 2003, hlm. 46.

7 Handri Raharjo, Hukum Perjanjian Di Indonesia, Pustaka Yustisia, Yogyakarta, 2009, hlm. 47. 
menerima menerima langsung jawaban dari pihak lawan.

Akibat hukum apabila tidak ada kesepakatan adalah perjanjian tersebut dapat dibatalkan melalui hakim (vernietigbaar, vidable).

2. Kecakapan

Kecakapan berbuat adalah kewenangan untuk melakukan perbuatan-perbuatan hukum sendiri. Subjek hukum yang cakap berbuat adalah orang dewasa, sehat akal pikiran dan tidak dilarang oleh undangundang. Kecakapan merupakan suatu istilah hukum, bukan sifat pembawaan karena tidak tertutup kemungkinan bahwa ia tidak sesuai dengan kenyataan. Orang yang secara yuridis tidak cakap, ada kemungkinan dalam kenyataanya adalah orang yang tahu atau sadar betul akan akibat atau konsekuensi dari tindakannya. ${ }^{10}$

Pada umumnya seseorang dikatakan cakap melakukan perbuatan hukum apabila sudah dewasa, yaitu mencapai umur 21 tahun atau sudah kawin walaupun belum 21 tahun. ${ }^{11}$ Berdasarkan Pasal 1330 KUH Perdata, seseorang dapat dikatakan tidak cakap apabila orang tersebut belum dewasa, orang yang berada di bawah pengampuan, dan wanita bersuami. Mereka dapat melakukan perbuatan hukum apabila diwakili oleh wali mereka
Akibat hukum dari ketidakcakapan dalam membuat perjanjian adalah perjanjian yang dibuat dapat dibatalkan melalui hakim. Jika pembatalan tidak dimintakan oleh pihak yang tidak berkepentingan dan sepanjang tidak dipungkiri oleh pihak yang berkepentingan maka perjanjian tersebut tetap berlaku bagi para pihak.

3. Suatu hal tertentu

Suatu hal tertentu adalah berupa objek perjanjian. Objek perjanjian adalah isi dari prestasi yang menjadi pokok perjanjian yang bersangkutan. ${ }^{12}$ Objek-objek perjanjian tersebut berupa: ${ }^{13}$

a. Objek yang akan ada (kecuali warisan), dapat ditentukan jenis dan dapat dihitung.

b. Objek yang dapat diperdagangkan (barang-barang yang dipergunakan untuk kepentingan umum tidak dapat dijadikan objek perjanjian).

Dalam Pasal 1333 KUH Perdata mengatakan bahwa suatu perjanjian harus mempunyai sebagai pokok suatu barang yang dapat ditentukan jenisnya dan jumlahnya dapat ditentukan dikemudian hari. Jika pokok perjanjian atau objek perjanjian tidak jelas, bahkan tidak mungkin untuk dilaksanakan, maka perjanjian tersebut batal (nietig, void).

\footnotetext{
10 J. Satrio, Hukum Perikatan, Perikatan Yang Lahir dari Perjanjian Buku II, PT Citra Aditya Bakti, Bandung, 1995, hlm. 3.

11 Abdulkadir Muhammad, Hukum Perdata Indonesia, PT Citra Aditya Bakti, Bandung, 1993, hlm. 231. Ibid. J. Satrio, Op.Cit., hlm. 32
} 


\section{Suatu sebab yang halal}

Sebab yang dimaksud adalah isi dari perjanjian itu atau tujuan dari para pihak mengadakan perjanjian. Halal adalah tidak bertentangan dengan undang-undang, ketertiban umum dan kesusilaan. Isi perjanjian tersebut harus halal karena isi perjanjian tersebut yang akan dilaksanakan. ${ }^{14}$

Akibat hukum perjanjian yang berisi kausa tidak halal adalah batal (nietig, void). Sehingga tidak ada dasar untuk menuntut pemenuhan perjanjian di muka hakim karena, karena sejak semula dianggap tidak pernah ada perjanjian dan perjanjian yang dibuat tanpa causa (sebab), dianggap tidak pernah ada seperti yang dikatakan dalam Pasal 1335 KUH Perdata, yaitu suatu persetujuan tanpa sebab, atau dibuat berdasarkan suatu sebab yang palsu atau yang terlarang, tidaklah mempunyai kekuatan. ${ }^{15}$

Apabila suatu kontrak bisnis dilakukan melalui e-commerce, maka kontrak yang terjadi adalah berupa kontrak online atau elektronik. Sehingga, dokumen-dokumen yang berhubungan dengan kontrak elektronik tersebut tidak tertuang dalam kertas, melainkan dalam bentuk dokumen elektronik.

Menurut Undang-Undang No. 11 Tahun 2008 tentang Informasi dan Transaksi Elektronik Pasal 1 butir 4 mendefinisikan dokumen elektronik adalah setiap informasi elektronik yang dibuat, diteruskan, dikirimkan, diterima, atau disimpan dalam bentuk analog, digital, elektromagnetik, optikal atau sejenisnya, yang dapat dilihat, ditampilkan, dan/atau didengar melalui komputer atau sistem elektronik, termasuk tetapi tidak terbatas pada tulisan, suara, gambar, peta, rancangan, foto atau sejenisnya, huruf, tanda, atau angka, kode akses, simbol, atau perforasi yang memiliki makna atau arti atau dapat dipahami oleh orang yang mampu memahaminya.

Namun, yang menjadi permasalahan adalah apakah dokumen elektronik dapat dijadikan alat bukti yang memiliki kekuatan hukum yang sama dengan dokumen tertulis di atas kertas yang diatur dalam Kitab Undang-Undang Perdata?

Di dalam Pasal 164 HIR/284 RBg dan Pasal 1866 KUH Perdata mengatur secara limitatif mengenai alat bukti dalam perkara perdata, yaitu:

1. Alat bukti tertulis;

Alat bukti tertulis ini diatur dalam Pasal 137, 138, 165, 167 HIR dan Pasal 164, 285, 305 RBg. Menurut Sudikno Mertokusumo, alat bukti tertulis atau surat adalah segala sesuatu yang memuat tanda-tanda baca, dimaksud untuk mencurahkan isi hati atau menyampaikan buah pikiran seseorang yang digunakan untuk pembuktian. Segala sesuatu yang tidak memuat tanda-tanda baca atau meskipun memuat tanda-tanda baca tetapi tidak mengandung buah pikiran, tidak termasuk dalam pengertian alat bukti tertulis atau surat. ${ }^{16}$

\footnotetext{
14 Handri Raharjo, Op.Cit., hlm. 57.

15 Abdulkadir Muhammad, Op.Cit,, hlm. 233.

16 Abdulkadir Muhammad, Op.Cit., hlm. 17.
} 
Surat (tulisan) merupakan alat bukti yang utama, karena dalam lalu lintas keperdataan, seperti jual beli, utang piutang, sewa menyewa dan sebagainya, orang memang dengan sengaja membuat alat-alat bukti yang akan digunakan (dipersiapkan) untuk membuktikan perbuatan hukum yang ia lakukan dikemudian hari seandainya timbul perselisihan, dan bukti yang disediakan tadi lazimnya bebentuk tulisan ${ }^{17}$.

Akta dibagi menjadi dua macam, yaitu: ${ }^{18}$

a. Akta otentik

Pasal 1868 KUH Perdata menjelaskan suatu akta otentik ialah akta yang dibuat dalam bentuk yang ditentukan undangundang oleh atau dihadapan pejabat umum yang berwenang untuk itu ditempat akta dibuat.

b. Akta di Bawah Tangan

Menurut Pasal 1874 KUH Perdata dan Pasal 286 RBg, akta di bawah tangan adalah tulisan atau akta yang ditandatangani di bawah tangan, tidak dibuat dan tidak ditandatangani di hadapan pejabat yang berwenang, tetapi dibuat oleh seseorang atau para pihak, secara umum terdiri dari segala jenis tulisan yang tidak dibuat oleh atau di hadapan pejabat, meliputi: surat-surat, register, surat urusan rumah tangga, lain-lain tulisan yang dibuat tanpa permintaan pejabat umum. Akta di bawah tangan adalah akta yang sengaja dibuat untuk pembuktian oleh para pihak yang berkepentingan tanpa bantuan dari pejabat yang berwenang.

2. Kesaksian (keterangan saksi) ${ }^{19}$

Kesaksian adalah kepastian yang diberikankepadahakim dipersidangan tentang peristiwa yang disengketakan dengan jalan pemberitahuan secara lisan dan pribadi oleh orang yang bukan salah satu pihak dalam perkara, yang dipanggil dipersidangan. Keterangan yang diberikan oleh saksi harus tentang peristiwa atau kejadian yang dialaminya sendiri, sedangkan pendapat atau dugaan yang diperoleh melalui berpikir tidaklah merupakan kesaksian.

3. Persangkaan-persangkaan ${ }^{20}$

Persangkaan merupakan alat bukti yang bersifat tidak langsung karena alat bukti persangkaan tidak dapat berdiri sendiri melainkan harus dengan perantaraan alat bukti lain. Dengan persangkaan suatu peristiwa dibuktikan secara tidak langsung artinya dengan melalui pembuktian peristiwa lain.

4. Pengakuan ${ }^{21}$

Pengakuan merupakan keterangan yang membenarkan peristiwa, hak

17 R. Subekti, Hukum Acara Perdata, Binacipta, Bandung, 1982, hlm. 89.

18 Handri Raharjo, Op.Cit., hlm. 64.

19 Efa Laela Fakhriah, Bukti Eleketronik Dalam Sistem Pembuktian Perdata, PT. Alumni, Bandung, 2009, hlm. 21-22.

$20 \quad$ Ibid., hlm. 23.

21 Ibid., hlm. 24-25. 
atau hubungan hukum yang diajukan oleh pihak lawan. Ilmu pengetahuan membagi pengakuan menjadi pengakuan murni dan pengakuan tambahan, sedangkan pengakuan dengan tambahan dibagi menjadi pengakuan dengan klasifikasi dan pengakuan dengan kualifikasi.

5. Sumpah. ${ }^{22}$

Sumpah pada umumnya adalah suatu pernyataan yang khidmat, diberikan atau diucapkan pada waktu memberikan janji atau keterangan dengan mmengingat sifat maha kuasa dari Tuhan, dan percaya bahwa siapa yang memberi keterangan atau janji atau keterangan yang tidak benar akan dihukum oleh Tuhan. HIR /RBg menyebutkan ada 3 macam sumpah sebagi alat bukti yaitu, sumpah pelengkap, sumpah pemutus, dan sumpah penaksir, yang diatur dalam Pasal 155158 dan 177 HIR (182-185 RBg).

Adapun alat bukti di luar kelima jenis alat bukti yang telah dijelaskan di atas, yaitu pemeriksaan setempat yang diatur dalam Pasal 153 HIR/ 180 RBG dan keterangan ahli atau saksi ahli yang diatur dalam Pasal 154 HIR/ 181 RBG.

\section{B. PEMBAHASAN}

Dalam transaksi e-commerce para pihak tidak bertemu secara langsung atau tidak bertatap muka pada saat melakukan transaksi. Mereka melakukan transaksi melalui perantara media elektronik. Oleh karena itu, kontrak yang dihasilkan dari transaksi tersebut berupa kontrak elektronik. Kontrak elektronik dalam transaksi elektronik, harus memiliki kekuatan hukum yang sama dengan kontrak konvensional. Kontrak elektronik harus juga mengikat para pihak sebagaimana Pasal 18 ayat (1) UU ITE menyebutkan bahwa transaksi elektronik yang dituangkan ke dalam kontrak elektronik mengikat para pihak.

Kontrak elektronik yang memiliki kekuatan hukum dan mengikat para pihak adalah kontrak yang sah. Salah satu unsur yang penting untuk terciptanya kontrak yang sah adalah adanya unsur kesepakatan. Jika kesepakatan diberikan secara tertulis, maka kontrak yang dihasilkan adalah kontrak tertulis. Sebaliknya kesepakatan yang diberikan secara lisan, kontrak yang dihasilkan adalah kontrak lisan. Sedangkan dalam kontrak e-commerce kesepakatan tidak diberikan dalam bentuk tertulis dan lisan, melainkan melalui media elektronik, sehingga sulit untuk menentukan kapan terjadinya suatu kesepakatan dalam kontrak e-commerce.

Kesepakatan dalam suatu kontrak terjadi apabila adanya pertemuan penawaran dan penerimaan dari masing-masing pihak. Ketika proses penawaran dan penerimaan melalui media elektronik berjalan melalui media maya, yang menimbulkan kesulitan dalam pembuktiannya, maka negara-negara yang tergabung dalam masyarakat ekonomi Eropa telah memberikan garis-garis petunjuk kepada para anggotanya untuk menjamin terlaksananya dengan tertib penawaran tadi. Semula petunjuknya dikenal sebagai sistem 3 klik. Pertama, setelah calon pembeli melihat layar di 
komputernya bahwa adanya penawaran dari calon penjual (klik pertama), maka calon pembeli memberikan penerimaan terhadap penawaran tersebut (klik kedua). Disampingadanya proses (klik) penawaran dan penerimaan masih ada disyaratkan adanya peneguhan dan persetujuan dari calon penjual kepada calon pembeli perihal diterimanya penerimaan dari calon pembeli (klik ketiga). ${ }^{23}$

Dari penjelasan di atas dapat telihat bahwa, lahirnya suatu kesepakatan dalam transaksi e-commerce adalah adanya penawaran dan penerimaan dari masing-masing pihak. Penjual melakukan penawaran melalui media elektronik dan pembeli menerima penawaran tersebut melalui media elektronik juga, lalu penjual mengkonfirmasikan kepada pembeli mengenai diterimanya penerimaan dari pembeli. Setelah melalui proses-proses tersebutlah kesepakatan dalam transaksi e-commerce tercipta.

Kontrak atau perjanjian yang dibuat dalam transaksi $e$-commerce adalah bukan kontrak atau perjanjian yang dibuat secara tertulis di atas kertas, melainkan berbentuk dokumen elektronik. Dalam transaksi jual beli pada umumnya, apabila terjadi sengketa para pihak dapat menggunakan kontrak atau perjanjian yang tertulis di atas kertas untuk dijadikan bukti telah terjadinya perjanjian jual beli diantara para pihak. Apabila perjanjian dalam bentuk dokumen elektronik sulit untuk dijadikan sebagai alat bukti apabila terjadi sengketa.
Hukum pembuktian Indonesia yang diatur dalam Pasal 164 HIR/284 RBg hanya mengatur mengenai alat bukti berupa surat, saksi, persangkaan, pengakuan, dan sumpah. Apabila dilihat dari pengertian dari setiap alat bukti tersebut, maka dokumen elektronik tidak termasuk dari alat -alat bukti tersebut. Jika dilihat dari kelima macam alat bukti tersebur dokumen elektronik hanya bisa di masukkan dalam kategori alat bukti tertulis. Dokumen elektronik ini merupakan tulisan yang dituangkan dalam sebuah surat elektronik dan tujuan dari pembuatan tulisan ini adalah untuk mewujudkan suatu kejadian yang telah terjadi dan menyatakan perbuatan hukum yang harus dilakukan oleh seseorang.

Sudikno Mertokusumo mendefinisikan alat bukti surat segala sesuatu yang memuat tanda-tanda bacaan yang dimaksudkan untuk mencurahkan isi hati atau untuk menyampaikan buah pikiran seseorang dan di pergunakan sebagai pembuktian. $^{24}$ Maksud dari pembuatan dokumen elektronik itu sendiri pun untuk digunakan sebagai alat bukti, sehingga dokumen elektronik dapat dikategorikan sebagai alat bukti.

Apabila dokumen elektronik dapat dijadikan alat bukti tertulis, maka yang harus dibuktikan adalah apakah dokumen elektronik memenuhi syarat-syarat dari alat bukti tertulis? Dalam Pasal 1 angka 4 UU ITE menjelaskan bahwa bentuk dokumen elektronik sangat beraneka ragam sangat bergantung pada maksud

23 Niniek Suparni, Cyberspace Problematika \& Antisipasi Pengaturannya, Penerbit Sinar Grafika, Jakarta, 2009, hlm. 68.

24 Sudikno Mertokusumo, Hukum Acara Perdata Indonesia, Penerbit Liberty, Yogyakarta, 2006, hlm. 149. 
penggunaan dari dokumen itu sendiri. Apabila dokumen elektronik itu hanya berupa informasi biasa maka dokumen itu termasuk dalam surat biasa karena dibuat seadanya dan tidak digunakan sebagai alat bukti nantinya. Namun jika dokumen itu dimaksudkan sebagai dokumen yang otentik, maka dokumen tersebut harus memenuhi beberapa persyaratan. Persyaratan utama agar dokumen elektronik itu dapat dinyatakan sebagai alat bukti yang sah adalah penggunaan sistem elektronik yang telah mendapatkan sertifikasi elektornik dari pemerintah seperti yang diatur dalam Pasal 15-16 UU ITE. Pasal 15 UU ITE menjelaskan bahwa:

1. Setiap Penyelenggara Sistem Elektronik harus menyelenggarakan Sistem Elektronik secara andal dan aman serta bertanggung jawab terhadap beroperasinya Sistem Elektronik sebagaimana mestinya;

2. Penyelenggara Sistem Elektronik bertanggung jawab terhadap Penyelenggaraan Sistem Elektroniknya;

3. Ketentuan sebagaimana dimaksud pada ayat (2) tidak berlaku dalam hal dapat dibuktikan terjadinya keadaan memaksa kesalahan, dan/ atau kelalaian pihak pengguna Sistem Elektronik.

Sedangkan dalam Pasal 16 UU ITE, dijelaskan bahwa setiap Penyelenggara Sistem Elektronik wajib mengoperasikan Sistem Elektronik yang memenuhi persyaratan minimum sebagai berikut:

1. Dapat menampilkan kembali Informasi Elektronik dan/atau Dokumen Elektronik secara utuh sesuai dengan masa retensi yang ditetapkan dengan Peraturan Perundang-undangan;
2. Dapat melindungi ketersediaan, keutuhan, keotentikan, kerahasiaan, dan keteraksesan Informasi Elektronik dalam Penyelenggaraan Sistem Elektronik tersebut;

3. Dapat beroperasi sesuai dengan prosedur atau petunjuk dalam Penyelenggaraan Sistem Elektronik tersebut;

4. Dilengkapi dengan prosedur atau petunjuk yang diumumkan dengan bahasa, informasi, atau simbol yang dapat dipahami oleh pihak yang bersangkutan dengan Penyelenggaraan Sistem Elektronik tersebut; dan

5. Memiliki mekanisme yang berkelanjutan untuk menjaga kebaruan, kejelasan, dan kebertanggungjawaban prosedur atau petunjuk.

Persyaratan yang lain, harus membubuhkan tanda tangan elektronik, dan menuangkannya dalam kontrak elektronik yang baku. Alat bukti tertulis terbagi atas akta otentik dan akta di bawah tangan. Apabila dilihat dari pengertian akta otentik berdasarkan pasal $1868 \mathrm{KUH}$ Perdata menjelaskan suatu akta otentik ialah akta yang dibuat dalam bentuk yang ditentukan undang-undang oleh atau di hadapan pejabat umum yang berwenang untuk itu di tempat akta dibuat. Dari penjelasan tersebut, dokumen elektronik tidak dapat dikatakan sebagai akta otentik karena berdasarkan Pasal 5 ayat (4) UU ITE menjelaskan bahwa:

$\begin{array}{lcc}\text { "Ketentuan } & \text { mengenai } & \text { Informasi } \\ \text { Elektronik } & \text { dan/atau } & \text { Dokumen } \\ \text { Elektronik } & \text { sebagaimana } & \text { dimaksud } \\ \text { pada ayat (1) tidak berlaku untuk: }\end{array}$


1. surat yang menurut UndangUndang harus dibuat dalam bentuk tertulis;

2. surat beserta dokumennya yang menurut Undang-Undang harus dibuat dalam bentuk akta notaril atau akta yang dibuat oleh pejabat pembuat akta."

Namun, dokumen elektronik elektronik dapat dikatakan sebagai akta di bawah tangan karena dokumen elektonik adalah akta yang sengaja yang sengaja dibuat untuk pembuktian oleh para pihak yang berkepentingan tanpa bantuan dari pejabat yang berwenang. Dari sudut pandang pembuktian agar suatu akta bernilai sebagai suatu akta di bawah tangan harus memenuhi syarat pokok, yaitu: ${ }^{25}$

1. Surat atau tulisan itu ditanda-tangani;

2. Isi yang diterangkan di dalamnnya menyangkut perbuatan hukum atau hubungan hukum;

3. Sengaja dibuat untuk dijadikan bukti dari perbuatan atau hubungan yang disebut di dalamnya.

Isi dokumen elektronik menerangkan mengenai perbuatan hukum yang dilakukan oleh para pihak dan tujuan dari pembuatan dokumen elektronik itu sendiri adalah untuk dijadikan alat bukti oleh para pihak yang membuat dokumen elektronik tersebut. Mengenai syarat bahwa akta di bawah tangan harus di tanda tangan, maka dalam dokumen elektronik tidak menggunakan tanda tangan seperti dokumen yang di atas kertas. Dalam dokumen elektronik yang digunakan adalah tanda tangan digital (digital signature).

Tanda tangan digital (digital signature) adalah suatu tanda tangan yang dibuat secara elektronik yang berfungsi sama dengan tanda tangan biasa pada dokumen kertas biasa. Tanda tangan digital tersebut pun harus memenuhi syarat-syarat agar dokumen elektronik dapat dikatakan sah sebagai alat bukti, seperti: ${ }^{26}$

1. Data pembuatan Tanda Tangan Elektronik terkait hanya kepada Penanda Tangan;

2. Data pembuatan Tanda Tangan Elektronik pada saat proses penandatanganan elektronik hanya berada dalam kuasa Penanda Tangan;

3. Segala perubahan terhadap Tanda Tangan Elektronik yang terjadi setelah waktu penandatanganan dapat diketahui;

4. Segala perubahan terhadap Informasi Elektronik yang terkait dengan Tanda Tangan Elektronik tersebut setelah waktu penandatanganan dapat diketahui;

5. Terdapat cara tertentu yang dipakai untuk mengidentifikasi siapa Penandatangannya; dan

6. Terdapat cara tertentu untuk menunjukkan bahwa Penanda Tangan telah memberikan persetujuan terhadap Informasi Elektronik yang terkait.

Dalam transaksi elektronik, seperti transaksi e-commerce, dokumen elektronik yang berasal dari Sistem Elektronik yang

\footnotetext{
25 M. Yahya Harahap, Hukum Acara Perdata, Penerbit Sinar Grafika, Jakarta, 2008, hlm. 590.

26 Pasal 11 UU No. 11 Tahun 2008 tentang Informasi dan Transaksi Elektronik.
} 
telah memenuhi syarat berdasarkan undang-undang dan terdapat tanda tangan digital (digital signature) yang telah disertifikasi (diakui keabsahannya) dapat dijadikan alatbukti apabila terjadi sengketa diantara para pihak yang melakukan transaksi e-commerce tersebut. Dokumen elektronik tersebut dapat dijadikan dasar atau alas, seperti kontrak atau perjanjian para pihak dalam melakukan transaksi e-commerce karena dokumen elektronik tersebut telah memenuhi syarat-syarat sahnya perjanjian, seperti kesepakatan, kecakapan, suatu hal tertentu dan sebab yang halal. Sehingga, dari penjelasan di atas dapat disimpulkan bahwa dokumen elektronik memiliki kekuatan hukum yang sama dengan dokumen tertulis di atas kertas dan dapat digunakan sebagai alat bukti apabila terjadi sengketa di antara para pihak.

\section{PENUTUP}

Dalam transaksi e-commerce, transaksi dilakukan tanpa kertas dan pihak tidak bertemu secara langsung. Dalam transaksi tersebut, dokumen tidak tersimpan dalam bentuk kertas, melainkan dalam bentuk dokumen elektronik. Dengan adanya transaksi yang berdasarkan dokumen elektronik, maka terjadi perubahan terhadap macam-macam alat bukti yang sudah ada sebelumnya yang digunakan untuk membuktikan adanya suatu perbuatan hukum dan dalam hukum pembuktian di Indonesia belum mengatur mengenai dokumen elektronik sebagai alat bukti.

Persyaratan utama agar dokumen elektronik itu dapat dinyatakan sebagai alat bukti yang sah adalah penggunaan sistem elektronik yang telah mendapatkan sertifikasi elektornik dari pemerintah seperti yang diatur dalam Pasal 15-16 UU ITE. Persyaratan yang lain, harus membubuhkan tanda tangan elektronik, dan menuangkannya dalam kontrak elektronik yang baku.

Alat bukti tertulis terbagi atas akta otentik dan akta di bawah tangan. Apabila dilihat dari pengertian akta otentik berdasarkan pasal 1868 KUH Perdata menjelaskan suatu akta otentik ialah akta yang dibuat dalam bentuk yang ditentukan undang-undang oleh atau di hadapan pejabat umum yang berwenang untuk itu di tempat akta dibuat. Dari penjelasan tersebut, dokumen elektronik tidak dapat dikatakan sebagai akta otentik.

Dokumen elektronik dapat dikategorikan sebagai alat bukti tertulis yang sah berupa akta di bawah tangan. Isi dokumen elektronik menerangkan mengenai perbuatan hukum yang dilakukan oleh para pihak dan tujuan dari pembuatan dokumen elektronik itu sendiri adalah untuk dijadikan alat bukti oleh para pihak yang membuat dokumen elektronik tersebut. Mengenai syarat bahwa akta di bawah tangan harus di tanda tangan, maka dalam dokumen elektronik tidak menggunakan tanda tangan seperti dokumen yang di atas kertas. Dalam dokumen elektronik yang digunakan adalah tanda tangan digital (digital signature). Sehingga memiliki kekuatan hukum yang sama dengan dokumen yang tertulis di atas kertas dan dapat dijadikan sebagai alat bukti apabila terjadi sengketa di antara para pihak dalam hal pembuktian adanya suatu perjanjian. 


\section{DAFTAR PUSTAKA}

Mariam Barus Badrulzaman, Aneka Hukum Bisnis, Alumni, Bandung, 1994.

Mariam Darus Badrulzaman, Mendambakan Kelahiran Hukum Saiber (cyber law) di Indonesia, Pidato diucapkan pada upacara memasuki masa Purna Bhakti sebagai Guru Besar Tetap Fakultas Hukum USU, Medan, Selasa 13 November 2001, bertempat di Hotel Danau Toba, Medan.

Efa Laela Fakhriah, Bukti Eleketronik Dalam Sistem Pembuktian Perdata, PT. Alumni, Bandung, 2009.

Munir Fuady, Pengantar Hukum Bisnis Menata Bisnis Modern di Era Global, PT. Citra Aditya Bakti, Bandung, 2002.

Johannes Gunawan, Reorientasi Hukum Kontrak di Indonesia, Jurnal Hukum Bisnis Volume 22 No. 6, Tahun 2003.

M. Yahya Harahap, Hukum Acara Perdata, Penerbit Sinar Grafika, Jakarta, 2008.

R. Eko Indrajit, Manajemen Sistem Informasi dan Teknologi Informasi, PT. Elex Media Komputindo, Jakarta, 2001.

Kisma Kartika, Karakteristik e-commerce, https://kismayuniputrikartika. wordpress.com/ diunduh tanggal 1 September 2015.

Sudikno Mertokusumo, Hukum Acara Perdata Indonesia, Penerbit Liberty, Yogyakarta, 2006.
Abdulkadir Muhammad, Hukum Perdata Indonesia, PT Citra Aditya Bakti, Bandung, 1993.

Handri Raharjo, Hukum Perjanjian di Indonesia, Pustaka Yustisia, Yogyakarta, 2009.

J. Satrio, Hukum Perikatan, Perikatan Yang Lahir dari Perjanjian Buku II, PT Citra Aditya Bakti, Bandung,1995.

R. Subekti, Hukum Acara Perdata, Binacipta, Bandung, 1982.

Niniek Suparni, Cyberspace Problematika \& Antisipasi Pengaturannya, Penerbit Sinar Grafika, Jakarta, 2009.

Kitab Undang-Undang Hukum Perdata.

Undang-Undang No 11 Tahun 2008 Tentang Informasi dan Transaksi Elektronik. 
